
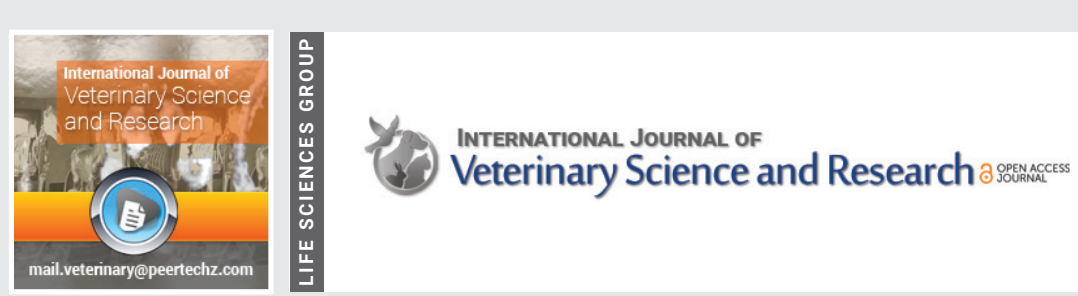

Retrospective Study

\title{
Retrospective study of
} livestock vaccine coverage and trend in Lemu and Bilbilo Woreda, Arsi Zone, Ethiopia

\author{
Debele Hordofa Feyisa*, Meseret kedir and Leta Shene
}

Ministry of Agriculture, Livestock Resource Sector, Addis Ababa, Ethiopia

Received: 12 October, 2021

Accepted: 27 October, 2021

Published: 28 October, 2021

*Corresponding author: Debele Hordofa Feyisa, Ministry of Agriculture, Livestock Resource Sector, Addis Ababa, Ethiopia, E-mail: debele99@gmail.com

Keywords: Data; Livestock; Species; Lemu and Bilbilo Woreda; Vaccine; Retrospective

Copyright: (c) 2021 Feyisa DH, et al. This is an openaccess article distributed under the terms of the Creative Commons Attribution License, which permits unrestricted use, distribution, and reproduction in any medium, provided the original author and source are credited.

https://www.peertechzpublications.com

Check for updates

\begin{abstract}
Vaccination is one of the most efficient tools for protection against clinical disease of livestock and reduces the rate of spread of infection. The study was conducted using secondary data that recorded at Lemu and Bilbilo Woreda veterinary clinic with the objective to assess the vaccination coverage in the study area from March to September 2021. Results revealed the most commonly practiced vaccine were bacterial and viral diseases from secondary data recorded were Lumpy skin disease, Black leg, Pasteurellosis, New castle, Gumboro disease, chicken pox, Fowl pox, and Fowl Cholera. The percentage of vaccine coverage for lumpy skin disease decreases from a year 2017 (51.1\%) to $2021(24 \%$ ). The majority of Goat (96.7\%) was vaccinated against goat pox during 2017 and the $0 \%$ Anthrax vaccine for Goat in 2021 . Only $7.3 \%$ sheep in 2017 and near $37.4 \%$ in 2021 were vaccinated with sheep pox from total population. About $87.4 \%$ of equines were vaccinated from total population in 2017 . The proportion of Newcastle disease and Gumboro disease vaccine coverage were $35 \%$ and $15.4 \%$, respectively. Dog vaccination against rabies is increases from a year 2017 $(4.8 \%)$ to $2020(11 \%)$ in except $0.5 \%$ in 2021 . The vaccine trends were fluctuating and/or decreasing from year to year. However, vaccine trend for Anthrax of cattle was increasing from year to year. It is therefore, suggested that implementation of planed and regularly vaccination of animal was very important for diseases control and prevention are recommended in order to decrease disease reoccurrence in the area.
\end{abstract}

\section{Introduction}

Livestock productions contribute an essential role both for the national economics and the livelihood of rural communities in sub-Saharan African countries like Ethiopia [1]. This is due to an important source of income-generating asset and wellbeing for rural family, but also it is the main source of food as well as insurance against future shocks and stresses [2].

Ethiopia is known for its highest number of livestock population in Africa because it has suitable agro-climatic condition for livestock production [3,4]. However, the country has not properly generated economy from livestock due to several factors such as poor management system, unimproved genetic potential, inappropriate disease prevention and control policy and lack of veterinary services and adequate infrastructure [5].

In Ethiopia, there is highly prevalent and economically importance of different disease affecting livestock were foot and mouth disease, Lumpy Sikn Disease (LSD), Anthrax, black leg, bovine pasteurelosis, Contagious Bovine Pleuropneumonia (CBPP), mastitis, bovine tuberculosis, bovine brucellosis, Contagious Caprine Pleuropneumonia (CCPP). In addition to this, bovine cysticercosis, toxoplsmosis, salmonellosis, , sheep pox, goat pox, camel pox, , Ovine pasteurelosis, external and internal parasites, Newcastle disease, Gumboro disease, Fowl Pox, Fowl Cholera, Fowl Typhoid and Coccidiosis were also the prevalent disease $[6,7]$. These diseases could lead to high number of direct and indirect economic losses in each year.

Vaccination is considered as one of the most efficient tools for protection against clinical disease of livestock and reduces the rate of spread of infection, but not totally eliminate the pathogen [8]. However, in Ethiopia, the percentage of animal vaccination coverage is relatively low. This is due to insufficient vaccines, lack of transport, inadequate refrigerator at veterinary clinic, lack awareness of the farmers and poor infrastructure [9]. 
Vaccination in mammals is normally carried out by inoculating vaccine (i.e. dead or attenuated bacteria or virus or some toxoid) into individual animals in order to produce active immunity against a specific infection; and/or to initiate or enhance protection of the host body against viral, bacterial or parasitic attacks [10]. Immunity is the power to resist infection or the action of certain poisons that generally produce from vaccine, sometimes from antiserum or antitoxin. Vaccination can also decrease excretion of pathogen by the infected animal; thereby reduce the chance of its dissemination to other animal species [11].

In Ethiopia, there are 8 bacterial vaccine like Anthrax, black leg, bovine pasteurelosis, CBPP, CCPP, ovine pasteurelosis, fowl cholera and fowl typhoid. And whereas 9 viral veterinary vaccines like Newcastle disease, Gumboro, Fowl Pox, Fowl Cholera, Fowl Typhoid, sheep and goat pox, camel pox, Africa Horse Sickness (AHS), LSD, rabies and peste des Petits Ruminants (PPR), were available and produced at Debre Zeit of the National Veterinary Institute (NVI) [12] . These are the only vaccine available in the country for protection of animal disease with low cost.

Data can obtain from secondary data resource that have been processed, organized and interpreted for some purpose so that someone can extract meaning from them, which is information. This data may obtain from clinical records, and records of diagnostic laboratory results with low cost [13]. With respect to this, there is very few published information describing the percentage animal vaccination coverage and trend in Ethiopia. Among a few study recently published on this issue based on the retrospective data to assess the animal vaccination coverage and trends of vaccination in Digelu-Tijo district [14]. Thus, the objective of this study was to assess the animal vaccination coverage and trends of vaccination for five years from 2017-2021 at lemu and bilbilo woreda in eastern Ethiopia.

\section{Materials and methods}

\section{Study area}

The study was conducted at Lemu and Bilbilo woreda in the Arsi zone, Eastern Ethiopia, from March 2021 to September 2021. Lemu and Bilbilo woreda is located $273 \mathrm{Km}$ east of from Addis Ababa. The woreda is situated between s between $7.55^{\circ} \mathrm{N}$ and $8.26{ }^{\circ} \mathrm{N}$ latitude and $39.23^{\circ} \mathrm{E}$ and $39.26^{\circ} \mathrm{E}$ longitudes with an elevation of $2810 \mathrm{~m}$. The district has 25 Village kebelas and 7 rural towns. The Woreda also livestock infrastructure which serve the town Bekoji and surrounding kebeles by 1 type " $\mathrm{B}$ " kilinic, 5 Type" C" Clinic 3 type" D" clinic they have. The area receives annual rain fall about $800-1200 \mathrm{~mm}$ and its elevation 2514-3800 above sea level. The agro ecology of the woreda is high land $(82 \%)$ and mid land (18\%). The Total population of Lemu and bilbilo Woreda estimated to be 185,789 households (CSA, 2017).

According to Lemu and Bilbilo Woreda Livestock Development Office [15], the area is characterized croplivestock mixed farming system. Teff, wheat, barley, maize, sorghum, peas, beans, chick-pea, lentils, linseeds, nug and rape seed are the major annual crops grown in the area. Whereas cattle, sheep, goats, horse, mules, donkey and poultry are the main livestock species raised in the zone.

\section{Study population}

Documented data on livestock vaccination coverage and trend in Lemu and Bilbilo Woreda from year 2017 to 2021 was used as study sample. The data record on vaccination which includes cattle, goat, sheep, equines, chicken and dogs species of animal; vaccine like Lumpy Skin Disease (LSD), Black leg, Anthrax for Cattle; Pasteurellosis, Sheep pox, goat Pox and anthrax for small ruminant, anthrax and Africa Horse Sickness (AHS) for equines, rabies vaccine for dogs; Newcastle disease, Fowl Pox, Fowl Typhoid, Gumboro disease (Infectious bursal) for chicken; from 2017-2021 year of were used for this study.

\section{Study design}

The retrospective study design was conducted to identify the vaccine coverage and trends in the study area. This was done by collecting retrospective data from all public veterinary Clinic in the districts that reported annually from 2017-2021 to Lemu and Bilbilo Woreda Livestock Development office (LBWLDO).

\section{Sampling methods}

A recorded secondary data on the percentage of animal vaccination was collected for numbers of cattle, equine, chicken, small ruminant as well as dog vaccination during study period regardless of age, breed and sex of animals and vaccine types used for the last five years (2017-2021) for the selected disease from LBLDO is used in the present study. The interim of type vaccine which is reported annually in the study is includes: LSD, Anthrax, Blackleg, AHS, Gumboro, Newcastle, and Rabies, which is frequency and regularly reported to LBWLDO.

\section{Data collection}

Five-year data (2017-2021) of livestock vaccine coverage reported and documented in the woreda is collected from data record book in Woreda Livestock Development Office. This data was entered, stored and coded in Microsoft Excel spreadsheet (Microsoft Corporation) and analyzed using SPSS version 22.0 statistical software.

\section{Data management and analysis}

Data obtained from recorded data were stored, filtered and coded in Microsoft Excel 2007 spreadsheet, and transferred to SPSS version 22.0 statistical software for statistical analysis. Descriptive statistics was used to determine vaccination coverage, define as proportion of animal species vaccinated to the total numbers of animal species registered per year during the five year period study (2017-2021). Summarized a percentage of vaccination coverage and trend was displayed by bar chart and line graphs.

\section{Results}

A finding of the present study shows that the vaccination percentage coverage of Lumpy Skin Disease (LSD) decreases 
from a year 2017 to 2021 , from $51.2 \%$ to $24 \%$. This is may be due to the decreases in the occurrence the diseases in the respective years. However, the vaccination coverage of anthrax arises from a year $2017(11.6 \%)$ to $2019-2020$ (18.5\%) but in $2021 \% 17.7$ it can be decrease. The lower percentage of black leg vaccine was countered in $2019(4.5 \%)$, whereas the higher percentage was recorded in 2020 (19\%) (Figure 1).

Sheep pox, anthrax and Ovine pasturella vaccine was used for sheep in the study area. The data recorded shows that Sheep pox vaccines coverage was $37.4 \% 2017$ in to $7.3 \%$ in 2021 which can be decreased from year to year. Ovine pasturellosis and Anthrax also low performance as shown below (Figure 2). Similarly, Goat Pox vaccines were used for goat with good vaccine coverage of goat pox $96 \%$ in 2017 compared to sheep vaccines (Figure 3).

Africa Horse Sickness (AHS) and anthrax vaccines were used for equines during study period in the Lemu and Bilbilo woreda. About $87.5 \%$ of equines were vaccinated from total population in 2017. Vaccination of equines against anthrax diseases was also practiced in the study area, but it not more meaning fully practices (Figure 4).

Fowl Typhoid, gumboro disease, fowl pox and Newcastle disease vaccine were used for chicken in the study area with a different vaccination percentage ranges. From this vaccination, the percentage of Newcastle disease vaccine was a better vaccination coverage which ranges $12 \%$ to $35 \%$ than the rest poultry diseases vaccination. However, the percentage of vaccination coverage for Fowl typhoid disease was $0.0 \%$ in 2019 and 2021. Vaccination percentage for infectious bursal disease (Gumboro disease) was raised from $1.6 \%$ (2017) to $15.4 \%$ (2021) due to the repeatedly re-occurrence of the disease encountered in the study area (Figure 5). Dog vaccination against rabies is arises from $4.8 \%$ (2017) to $11.0 \%$ (2020). However, a decrease in rabies vaccine coverage only was observed in the year 2021 (Figure 6).

\section{Discussion}

The present study has revealed that various vaccines were administered to sheep, goat, cattle, and equines, chicken as well as dogs in Lemu and Bilbilo woreda during study period with different vaccination coverage ranges as show in the result. Among vaccine used in the area; vaccine like LSD, Black leg, Anthrax for Cattle; Pasteurellosis, Sheep pox, Goat Pox and anthrax for small ruminant, anthrax and Africa horse sickness for equines and rabies vaccine for dogs. Similarly, vaccines like Newcastle disease, Fowl Pox, Fowl Typhoid, Gumboro disease were used for chicken in order to decrease re-occurrence of animal disease in the area.
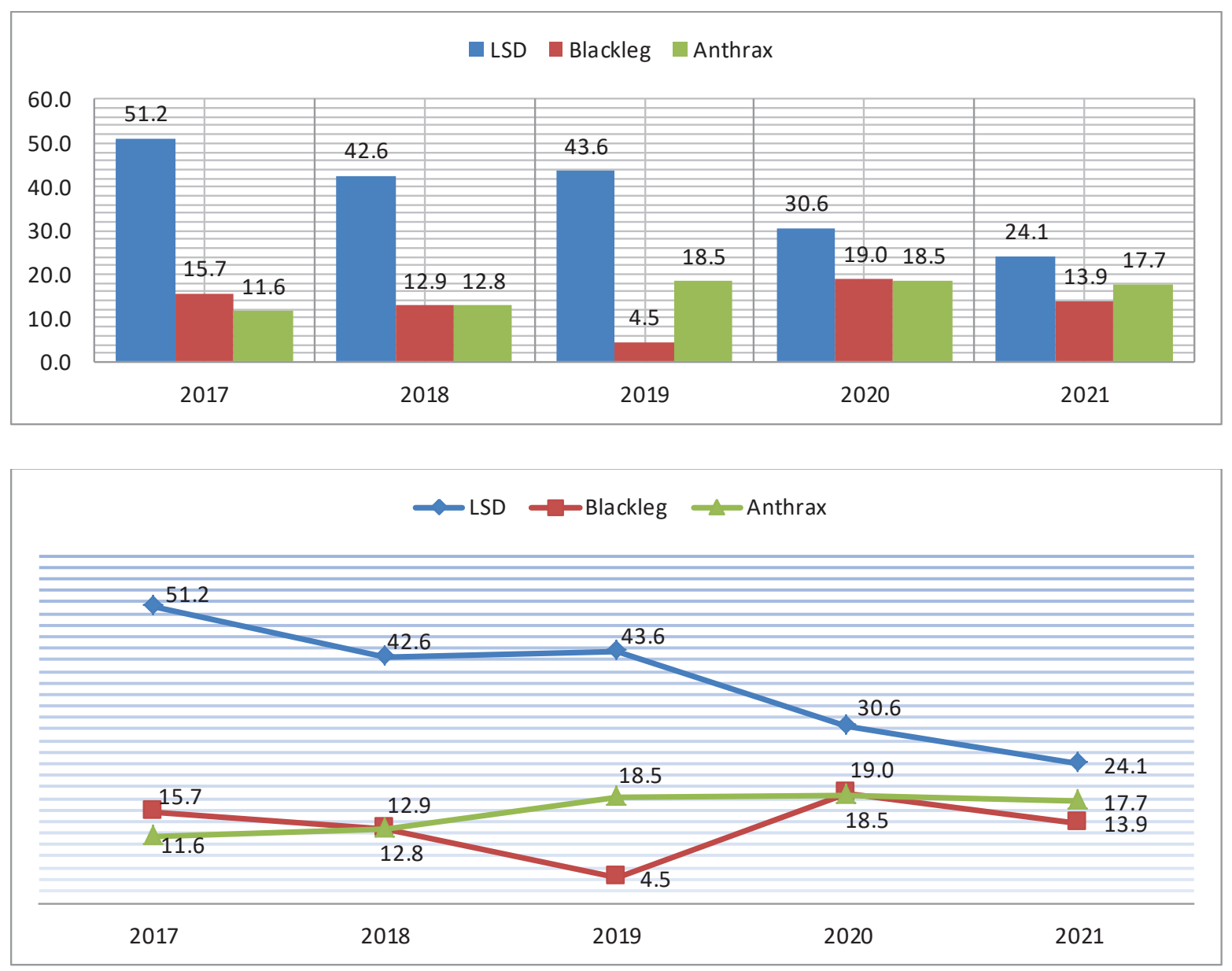

Citation: Feyisa DH, Kedir M, Shene L (2021) Retrospective study of livestock vaccine coverage and trend in Lemu and Bilbilo Woreda, Arsi Zone, Ethiopia. Int J Vet Sci Res 7(2): 144-150. DOI: https://dx.doi.org/10.17352/ijvsr.000094 

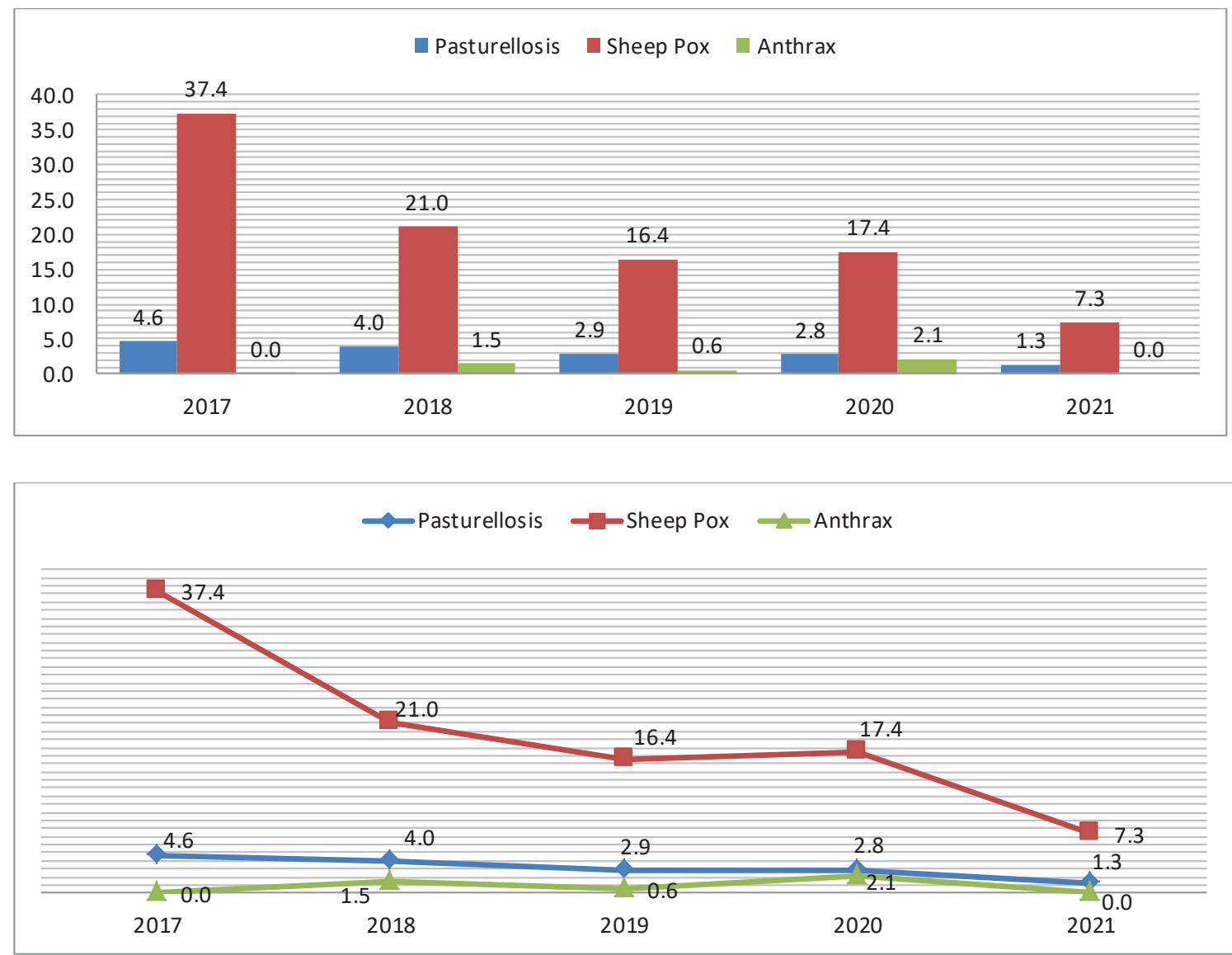

Figure 2: Sheep percent of vaccine coverage and trend in Lemu and Bilbilo district from 2017-2021.

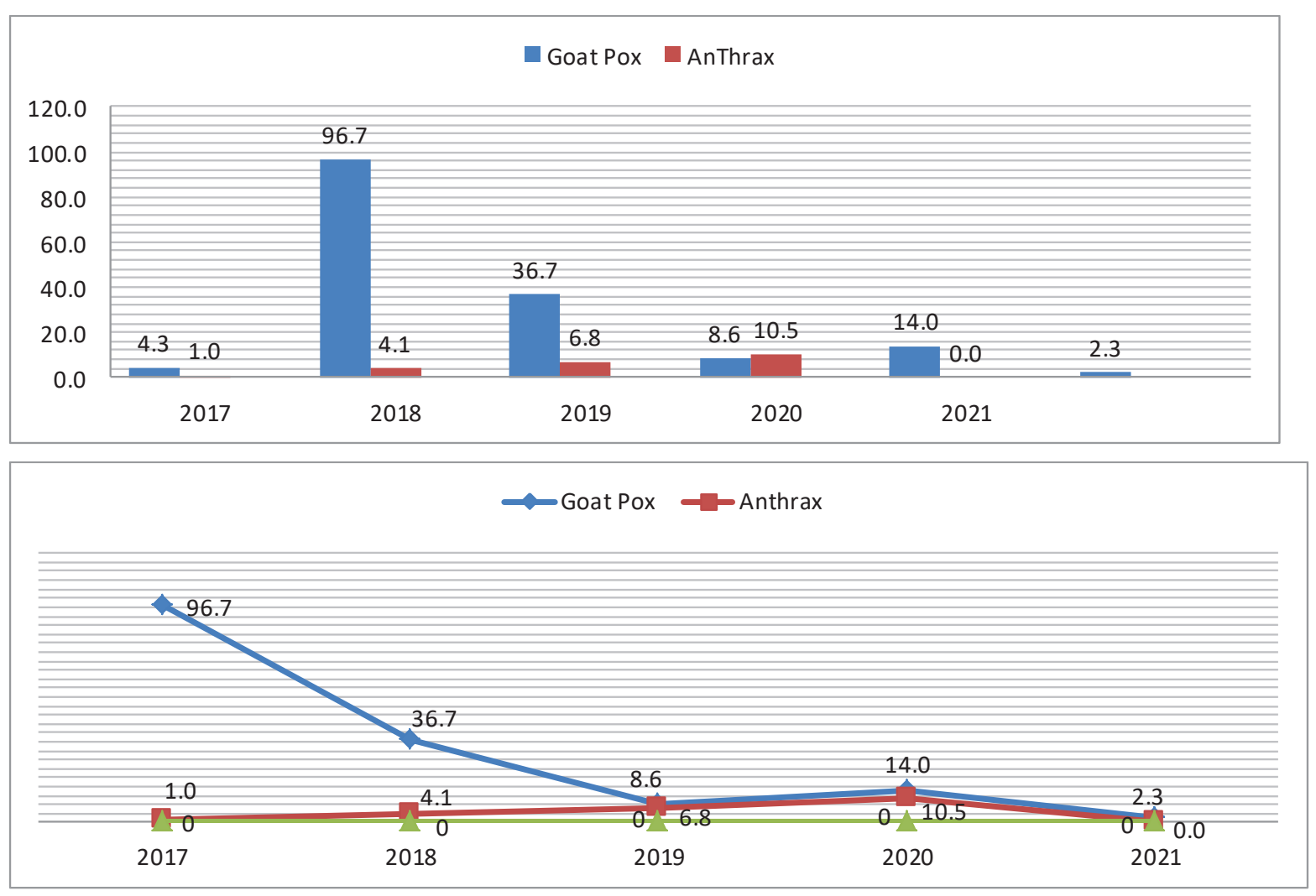

Figure 3: Goat percent of vaccine coverage in Lemu and Bilbilo district from 2017-2021.

Citation: Feyisa DH, Kedir M, Shene L (2021) Retrospective study of livestock vaccine coverage and trend in Lemu and Bilbilo Woreda, Arsi Zone, Ethiopia. Int J Vet Sci Res 7(2): 144-150. DOI: https://dx.doi.org/10.17352/ijvsr.000094 

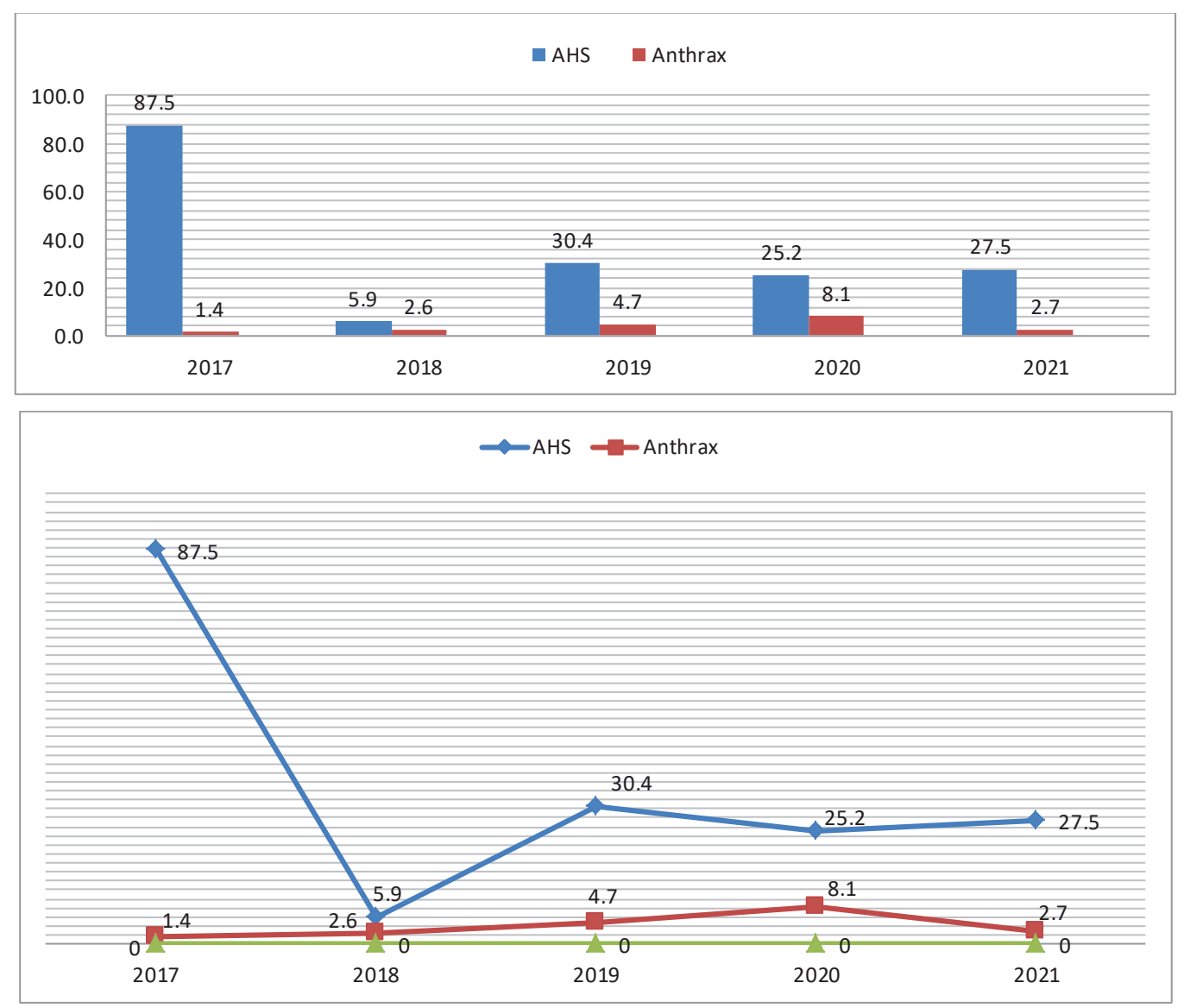

Figure 4: Equine \% vaccine coverage and trend in Lemu and Bilbilo district from 2017-2021.
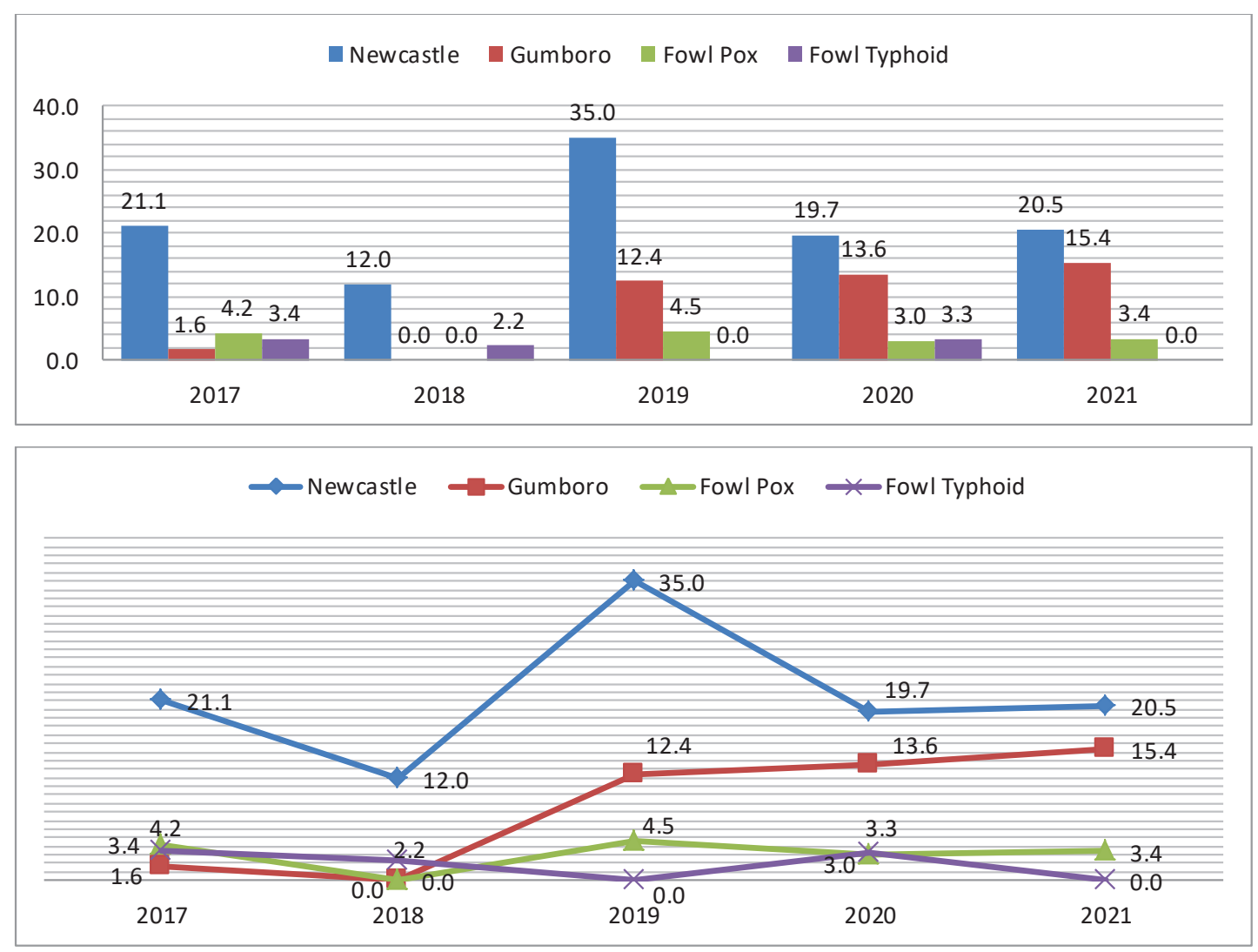

Figure 5: Chicken \% vaccine coverage and trend in Lemu and Bilbilo district from 2017-2021.

Citation: Feyisa DH, Kedir M, Shene L (2021) Retrospective study of livestock vaccine coverage and trend in Lemu and Bilbilo Woreda, Arsi Zone, Ethiopia. Int J Vet Sci Res 7(2): 144-150. DOI: https://dx.doi.org/10.17352/ijvsr.000094 

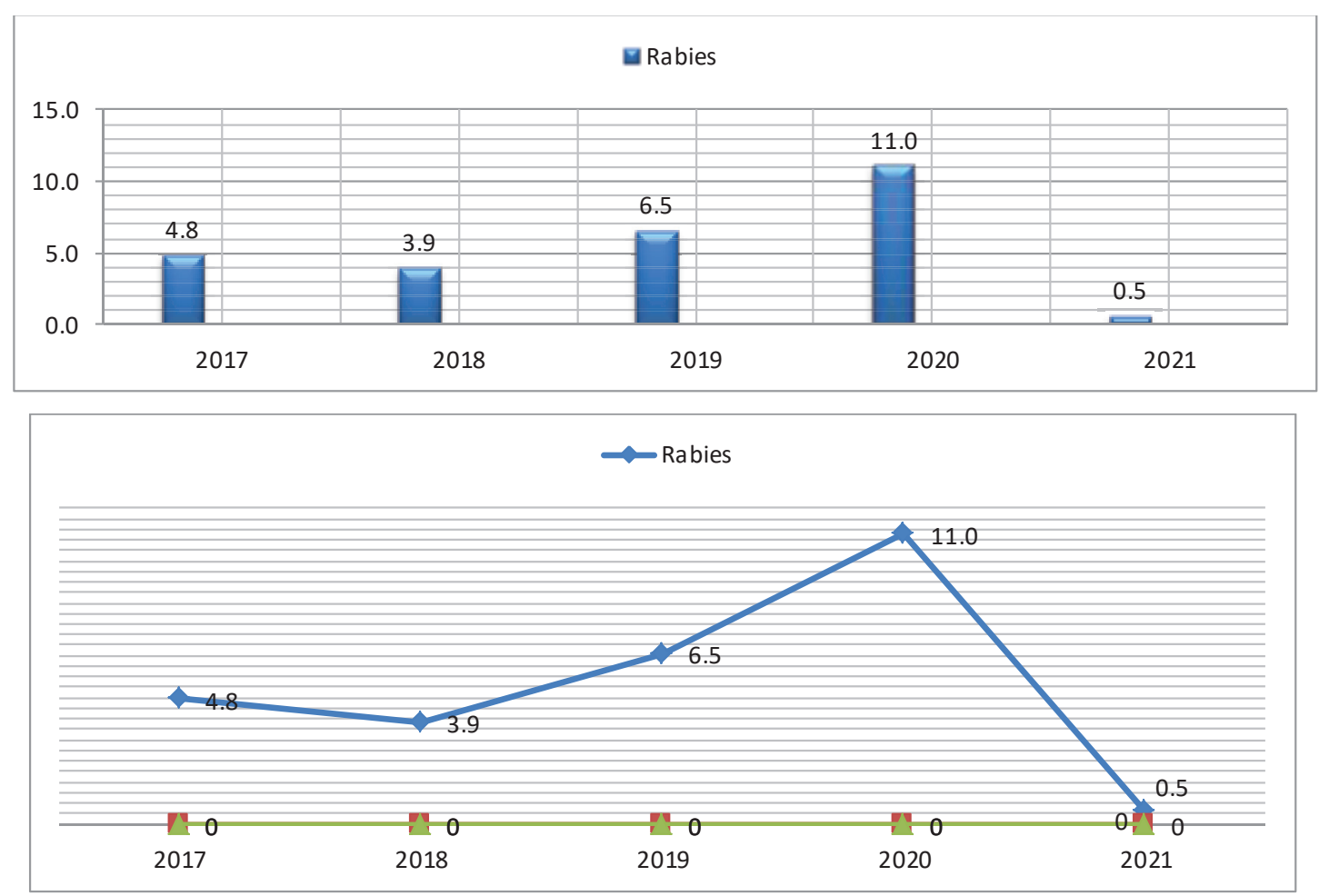

Figure 6: Dog \% vaccine coverage and Trend in Lemu and Bilbilo district from 2017-2021.

The present findings show that the vaccine coverage in Lemu and Bilbilo Woreda was low as compared with the livestock population in the study area. This finding is similar with that of report of Mulualem and Fekadu [14] who stated low vaccine coverage compared with the livestock population in the area. This is may be due almost similarly veterinary infrastructures and veterinary service activities in the two areas.

In the study area, the percent of cattle vaccination against LSD decreases from $51.2 \%$ to $24 \%$, from a year 2017 to 2021 . This finding is against with the finding reported by Mulualem and Fekadu [14], which show that Lumpy Skin Disease vaccine was increasing year to year, from $10 \%$ to $19 \%$. This may be at study area in one year in 2017 a mass of population was vaccine that protected animal for next some year. Furthermore, the percentage of cattle vaccination against Anthrax disease was very low $17 \%$ compared with the rest vaccination coverage, as almost $83 \%$ of population did not cover during mass vaccination. However, Sarker, et al. (2020) which were conducted in Bangladesh $44 \%$ of the cattle were covered in mass vaccination campaign. This show that higher percentage of cattle population was at the risk of disease development at given in time.

Sheep pox, goat pox, pasteurellosis and anthrax vaccines was used for sheep and goat in the study area. In the present study, Sheep and Goat pox vaccines coverage was decreased from year to year. The finding of the present study is agreement with Mulualem and Fekadu [14] who reported decreasing sheep pox vaccines coverage from year to year.

In line with current finding, Tadege and Afera [16] who reported only black leg vaccine coverage that show increase in performance from year to year. This show that black leg disease was the main soil borne infection disease affecting cattle population.

In the present study area, there is no planed and regularly vaccination schedule in order to prevent and control animal disease, only vaccination process is conducted during disease outbreak as ring vaccination and annual blanket vaccination. Because of this, effectiveness of disease prevention and control is low. In addition to this, the supply of vaccines and logistic required for vaccination process is absent in the area. Due to these limitations, the vaccination coverage in the woreda is less than $50 \%$.

However, for effective disease prevention and control program in the area, all the animal population for any disease should be vaccinated regularly before the disease outbreaks for successful vaccination as it stated by Melesse [11].

\section{Conclusion and recommendation}

Present study show that Anthrax, Blackleg, AHS, LSD and Rabies were the most common disease affecting livestock in the study area as evidenced from the clinical record of the past five years. Whereas Newcastle, Gumboro, Fowl Pox and Fowl Typhoid were a common causes of chicken diseases. These disease were highly affect the animal at different time due to unplanned and irregularly vaccination schedule on the top of absent vaccines stocks in the vaccine production Centre in the country or woreda that lead to lower vaccination coverage. Therefore, there is an urgent need to implement feasible interventions in study area in order to provide effective control 
of the disease prevalence and improving the health of animals; the following recommendations are forwarded:

$>$ Planed and regularly vaccination schedule is needed in the area in order the percentage of vaccination coverage.

$>$ Improving low performance and decreasing trends of vaccination after outbreak.

$>$ Long-term researches should be done to investigate rate of disease outbreak, transmission, predisposing factors as well as its association.

$>$ Enhancing the awareness of farmers through continuous education and improving the way of vaccination delivery for animal as the most practical measures to reduce disease occurrence in the study area.

$>$ In study time data shows that the plan of livestock office in the district was perform the zonal deducted annual plan which is not from total population .So that the office should plan from the total population of the district.

\section{References}

1. ILCA (International livestock center for Africa) (1998) Animal reproduction for African a joint semin by international foundation for science and Swedish international countries, report of program on animal production ILCA, Addis Ababa, Ethiopia.

2. Moyo S, Wanepoel F (2010) Multi functionality of livestock in developing communities and the role of livestock in developing communities. The Technical Centre for Agricultural and Cooperation and University of the Free State 345-356. Link: https://bit.ly/3pGRk4Z

3. Tegegne A, Gebrewold A (1998) Prospects for peri-urban dairy development in Ethiopia. In: Stoltenow, C.L. and Vincent L.L. (2003): Proceeding of $5^{\text {th }}$ national conference, the Ethiopian society of animal production (ESAP), 15-17 May 1997, Addis Ababa, Ethiopia. 28-39. Link: https://bit.ly/3EkrTKD

4. CSA (2015) Report on livestock and livestock characteristics. The Federa Democratic republic of Ethiopia, Private Peasant Holdings. Statistical Bulletin 570, Addis Ababa, Ethiopia 21-29.
5. Ayele S, Assegid W, Belachew H, Jabbar M, Ahmed M (2003) Livestock marketing in Ethiopia: A review of structure, performance and development initiatives. Socioeconomic and Policy Research Working Paper 52. International Livestock Research Institute, Addis Ababa, Ethiopia. Link: https://bit.ly/3nBV5Gx

6. Yearbook PA (2011) Inter-African Bureau for Animal Resources African Union, Nairobi, Kenya.

7. Gizaw S, Desta H, Alemu B, Tegegne A, Wieland B (2020) Importance of livestock diseases identified using participatory epidemiology in the highlands of Ethiopia. Trop Anim Health Prod 52: 1745-1757. Link: https://bit.ly/3jElhyM

8. Radostitis O, Gay C, Hincwiff K, Constabl P (2007) Veterinary medicince a text book of the disease of cattle, Horses, Sheep, Pigs and Goats, $10^{\text {th }}$ ed. Saunders Elsevier London. New York 1576-1580. Link: https://bit.ly/3EmZsM6

9. Cooper BJ, Valentine BA (2016) Muscle and tendon, In: Maxie MG (Eds.), Jubb, Kennedy, and Palmer's Pathology of Domestic Animals. (6th edn), Elsevier 164-249.

10. Boden E (2005) Black's Veterinary Dictionary, $21^{\text {th }}$ ed. London: Black publisher Ltd 791. Link: https://bit.ly/3GqXNa9

11. Mellese N (2004) Veterinary Management. Presented in the Workshop on PANVAC activities on quality control of vaccine, held on March 14-16, Debrezeit, Ethiopia

12. MoA (Ministry of agriculture) (2011) Ethiopia Animal Health Yearbook Ministry of Agriculture Animal and Plant Health Regulatory Directorate, Addis Ababa, Ethiopia.

13. Thrusfield M, Christley R, Brown H, Diggle PJ, French N, et al. (2018) Veterinary Epidemiology. $4^{\text {th }}$ ed. John Wiley and sons Ltd, The Atrium, South Gate, Chichester, West Sussex, UK 464-488. Link: https://bit.ly/3GqXNqF

14. Mulualem A, Fekadu S (2020) Retrospective study on livestock vaccine coverage and trends in Digelu-Tijo district, Arsi zone. Int J Agric Ext 219-224. Link: https://bit.ly/3CkecuT

15. Lbwldo (2013) Lemmu and Bilbilo Woreda Livestock Development Office. Annualy report.

16. Tadege A, Afera B (2016) Assessment of Vaccination Coverage of Sheep and Goat using Retrospective Data in Woreda Raya Alamata. Momona Ethiopian Journal of Science 8: 83. Link: https://bit.ly/3jlERKy

Discover a bigger Impact and Visibility of your article publication with

Peertechz Publications

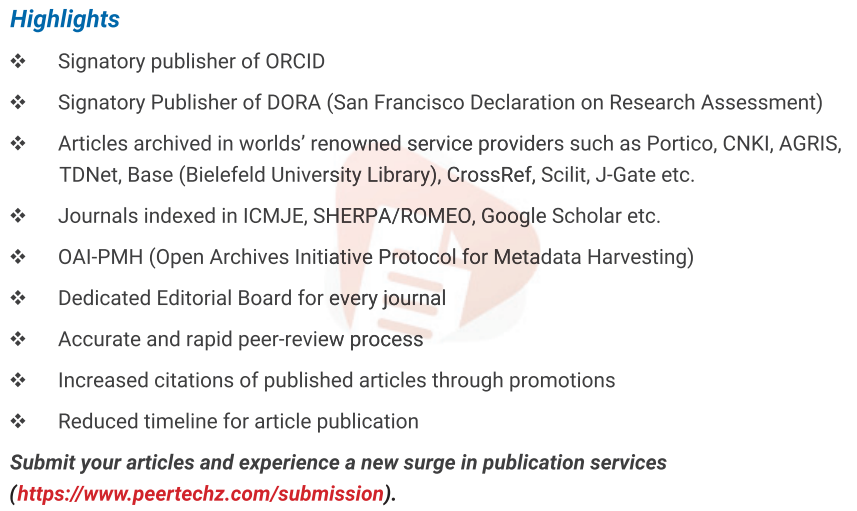

Peertechz journals wishes everlasting success in your every endeavours.

Citation: Feyisa DH, Kedir M, Shene L (2021) Retrospective study of livestock vaccine coverage and trend in Lemu and Bilbilo Woreda, Arsi Zone, Ethiopia. Int J Vet Sci Res 7(2): 144-150. DOI: https://dx.doi.org/10.17352/ijvsr.000094 